\title{
Delayed-release oral suspension of omeprazole for the treatment of erosive esophagitis and gastroesophageal reflux disease in pediatric patients: a review
}

This article was published in the following Dove Press journal:

Clinical and Experimental Gastroenterology

26 March 2010

Number of times this article has been viewed

\author{
Alice Monzani \\ Giuseppina Oderda \\ 'Department of Pediatrics, Università \\ del Piemonte Orientale, Novara, Italy
}

Correspondence: Giuseppina Oderda Department of Pediatrics, Università del Piemonte Orientale, Via Solaroli 17, 28100 Novara, Italy

$\mathrm{Tel}+3903213733868$

Fax +390321 3733598

Email oderda@med.unipmn.it

\begin{abstract}
Omeprazole is a proton-pump inhibitor indicated for gastroesophageal reflux disease and erosive esophagitis treatment in children. The aim of this review was to evaluate the efficacy of delayed-release oral suspension of omeprazole in childhood esophagitis, in terms of symptom relief, reduction in reflux index and/or intragastric acidity, and endoscopic and/or histological healing. We systematically searched PubMed, Cochrane and EMBASE (1990 to 2009) and identified 59 potentially relevant articles, but only 12 articles were suitable to be included in our analysis. All the studies evaluated symptom relief and reported a median relief rate of $80.4 \%$ (range $35 \%-100 \%$ ). Five studies reported a significant reduction of the esophageal reflux index within normal limits $(<7 \%)$ in all children, and 4 studies a significant reduction of intra-gastric acidity. The endoscopic healing rate, reported by 9 studies, was $84 \%$ after 8 -week treatment and $95 \%$ after 12 -week treatment, the latter being significantly higher than the histological healing rate (49\%). In conclusion, omeprazole given at a dose ranging from 0.3 to $3.5 \mathrm{mg} / \mathrm{kg}$ once daily (median $1 \mathrm{mg} / \mathrm{kg}$ once daily) for at least 12 weeks is highly effective in childhood esophagitis.
\end{abstract}

Keywords: proton pump inhibitors, children, ranitidine, H2-blockers

\section{Introduction}

\section{Gastroesophageal reflux disease and erosive esophagitis} in pediatric patients: symptoms and therapeutic approaches Gastroesophageal reflux disease (GERD) is defined as the presence of regurgitation of the gastric contents into the esophagus (gastroesophageal reflux) associated with troublesome symptoms and/or complications. ${ }^{1}$ Although different abnormalities in motility variables, such as lower esophageal sphincter function, esophageal peristalsis and gastric motor activity can contribute to the development of GERD, the degree of esophageal acid exposure represents the key factor in its physiopathology. GERD is the most common esophageal disorder in childhood and the most frequent reason why infants are referred to the pediatric gastroenterologist, affecting as much as $1.8 \%$ to $8.2 \%$ of the pediatric population. ${ }^{2}$ Presenting features of GERD in infants and children are quite variable and follow patterns of gastrointestinal and extra-intestinal manifestations that may vary according to age. Patients may be minimally symptomatic, or may exhibit severe esophagitis, bleeding, failure to thrive, or severe respiratory problems. Symptoms of GERD may include: regurgitation, persistent vomiting, anorexia/feeding refusal, hypersalivation, arching, irritability, persistent crying, abdominal and epigastric pain, heartburn, chest 
pain, sleep disturbances, ${ }^{3,4}$ Sandifer's syndrome (head turning episodes to lengthen the esophagus, repetitive stretching and arching, which gives the appearance of seizure/dystonia), ${ }^{5}$ dental erosion, ${ }^{6}$ and many other extra-intestinal manifestations, mainly respiratory symptoms such as stridor, recurrent wheezing, cough, chronic laryngitis, hoarseness, asthma. ${ }^{7-9}$ In the more severe forms of GERD esophageal complications like erosive or ulcerative esophagitis, ${ }^{10}$ hemorrhage, stricture, Barrett's esophagus ${ }^{11,12}$ may be diagnosed.

The main aims of the treatment of GERD in children are to relieve symptoms, promote normal growth and prevent the afore-mentioned complications. Conservative measures include parent reassurance, positioning and altering feed consistency. Treatment options include decreasing intra-gastric acidity with antacids, histamine $\mathrm{H}_{2}$ receptor blockers and proton pump inhibitors (PPI) and correcting gut motility with prokinetics, such as metoclopramide and domperidone. Surgical approaches like fundoplication are typically reserved to children with severe GERD refractory to medical treatment.

A recent systematic review about the pharmacological management of GERD in children ${ }^{13}$ suggested the only safe and effective medications are ranitidine and omeprazole and probably lansoprazole, being able to promote symptomatic relief, and endoscopic and histological healing of esophagitis. In particular, omeprazole is reported to be effective in children with GERD refractory to ranitidine treatment and should be a first-line treatment in severe esophagitis. ${ }^{13}$

\section{Omeprazole pharmacology and pharmacokinetics}

Omeprazole is a PPI blocking the final common pathway of acid secretion at the luminal surface of the parietal cell by binding to $\mathrm{H}^{+} \mathrm{K}^{+}$-ATPase, the so-called "acid pump" or "proton pump" thereby providing potent suppression of gastric acid output. The pro-drug omeprazole is rapidly and almost completely absorbed, with peak plasma levels occurring 1 to 3 hours after ingestion. It is highly (95\%) protein-bound and rapidly distributed in plasma. The pro-drug is rapidly metabolized by hepatic cytochrome P-450 isoenzyme CYP2C19, resulting in a very short plasma half-life of 40 to 60 minutes. ${ }^{14}$ Despite its relatively short plasma half-life, clinically adequate suppression of acid secretion lasts 12 to 15 hours after a single morning dose, because of the covalent binding of omeprazole with the parietal cell proton-pumps exposed toward the gastric lumen. Thus, the anti-secretory effect of omeprazole is not dependent on its plasma concentration at any given time but it is directly proportional to the area under the plasma concentration curve (AUC). ${ }^{14}$ Omeprazole pharmacokinetic studies in children shows that younger ones tend to have a higher metabolic capacity, resulting in a shorter half life of the drug. This may explain the need for higher doses of omeprazole on a per kilogram basis in children as compared to adults, and even higher in children younger than 6 years of age. ${ }^{15}$

\section{Omeprazole formulations}

Omeprazole is approved for the treatment of GERD and erosive esophagitis in children $\geq 2$ years both by European and US indications.

Omeprazole is commercially available in capsules containing enteric-coated, delayed-release granules that should not be chewed or crushed because of their acid liability. For children who have difficulty in swallowing them, the capsules may be opened and the granules sprinkled on applesauce or yogurt or dispersed in fruit juice or swallowed immediately with water. However, if the child accidentally chews the granules, their bitter taste may result in non-compliance with refusal of subsequent doses. ${ }^{16}$ In two studies ${ }^{17,18}$ omeprazole granules have been dissolved in an alkaline vehicle $(8.4 \%$ bicarbonate at a concentration of $2 \mathrm{mg} / \mathrm{mL}$ ) or in milk. The pharmacodynamic resulting from these alternative methods of omeprazole administration has been reported to be the same as for the intact capsule. ${ }^{19}$ Use of an extemporaneously prepared flavored omeprazole suspension may increase compliance and palatability in pediatric patients. However, the oral bioavailability of omeprazole in non-proprietary formulations has not been accurately assessed yet.

\section{Omeprazole safety and tolerability}

The safety and tolerability of omeprazole in both short- and long-term use is demonstrated by the scarcity of adverse effects in spite of extensive use reported in several studies. Most common reported adverse effects have been nausea, vomiting, diarrhea, epigastric pain, skin rash, and irritability ${ }^{17,20-22}$ but generally no severe enough for patient to discontinue the drug. Only one case of anaphylactic reaction due to omeprazole has been reported, in a 14-year-old boy. ${ }^{23}$ One recent study reported the association of omeprazole and an increased risk of acute gastroenteritis and communityacquired pneumonia in children. ${ }^{24}$ Hypergastrinemia, ${ }^{22,25-27}$ parietal cell hyperplasia, ${ }^{28}$ and occasionally gastric polyps ${ }^{29,30}$ have also been described in children receiving long-term omeprazole therapy. These changes are usually histologically benign. No statistically significant differences in gastrin level according to omeprazole dosage, dosing frequency or treatment duration has been reported. ${ }^{21}$ And no correlation between the degree or duration of hypergastrinemia and the 
presence of polyps or parietal cell changes. A mild elevation in transaminase levels has been reported..$^{25}$ Therefore, both short- and long-term omeprazole therapy appears to be safe and well tolerated in children despite some biochemical, endoscopic, and histologic changes..$^{20,21}$

\section{Drug interactions}

Omeprazole appears to interact with only one P-450 isoenzyme, CYP2C19. ${ }^{31}$ Thus it is expected to have a narrow spectrum of interaction limited to drugs metabolized by this enzyme. However, interactions with diazepam, phenytoin, warfarin, digoxin, or methotrexate are reported as not clinically significant. ${ }^{31-36}$ There is no effect of omeprazole on metabolism of several other drugs tested like theophylline, ${ }^{37,38}$ propranolol $^{39}$ or cyclosporine. ${ }^{40}$

\section{Materials and methods Literature search}

We systematically searched PubMed, Cochrane and EMBASE (1990 to 2009) to identify studies evaluating the efficacy of delayed release oral suspension of omeprazole for the treatment of erosive esophagitis and gastroesophageal reflux in children. The search terms used included: "omeprazole", "gastroesophageal (or gastro-oesophageal) reflux", "erosive esophagitis (or oesophagitis)", "child\$" (or "infant\$") and "drug\$" or "therapy" or "treatment". These terms were combined in various ways to generate a wide search. In addition, we checked references of eligible articles for further papers that were not captured by our search strategy and corresponded with authors when a full-length article was not available directly on-line or when relevant information was missing in the paper.

\section{Inclusion criteria}

We included articles that met the following pre-determined criteria: a) clinical trials performed in pediatric patients reporting on efficacy of omeprazole for the treatment of erosive esophagitis and gastroesophageal reflux in children, b) only delayed release omeprazole as oral suspension: ie, powder for oral suspension (Prilosec) or capsule content in liquid vehicle or non-encapsulated intact enteric-coated granules administered with fluids, c) studies in English language, d) studies with adequate data about number and age of treated children, endoscopic diagnosis, total daily dose and duration of treatment.

\section{Data extraction and synthesis}

A form was generated to register whether individual studies met eligibility criteria and collect data regarding study design and methodological quality. Two investigators independently reviewed and extracted data from the papers according to the pre-determined criteria. Any differences in opinion about the studies were resolved by discussion between them.

\section{Outcomes}

Our analysis focused on the following measures of therapeutic efficacy: GERD symptom relief/resolution, reduction in reflux index, endoscopic and/or histological healing of esophagitis.

\section{Analysis}

Selection bias and lack of common outcome measures were some of the problems preventing a proper metanalysis. Therefore, we defined subgroups for the analysis by dividing studies into 3 groups according to the outcome measures considered in each paper: a) GERD symptom relief/resolution, b) reduction in reflux scores as documented by 24-hour esophageal and/or gastric pH-monitoring, and c) endoscopic and/or histological healing of esophagitis.

\section{Results}

Our literature search identified 59 potentially relevant articles. After reviewing the titles and abstracts and the fulllength articles, 12 articles were selected for closer assessment and then included in our analysis. ${ }^{17,18,22,25-27,41-46}$ They are summarized in Table 1.

Of the 12 selected studies, 10 were controlled trials, 2 were randomized controlled trials ( 1 was placebo-controlled ${ }^{41}$ and the other compared omeprazole to ranitidine ${ }^{27}$ ). Ten were single-center studies, 2 were multi-center studies ( 1 of them was multinational ${ }^{42}$ ). Overall, data from a total of 262 children were reported. Children's age showed a wide range of variability ranging from 1.25 months to 18 years. The treatment duration varied widely, ranging from 2 to 24 weeks, but after 2 weeks only intra-esophageal and/or gastric $\mathrm{pH}$ was evaluated in 2 studies $^{17,41}$ and in 1 study also endoscopy was performed as early as within 2 weeks. ${ }^{22}$ The median dose of omeprazole was $1 \mathrm{mg} / \mathrm{kg}$ once daily (range $0.26-3.5 \mathrm{mg} / \mathrm{kg}$ ). In all studies omeprazole was administered as a capsule or as the capsule content dispersed in a weakly acid vehicle, except for 2 studies $^{17,18}$ where granules were dispersed in non-acid vehicles.

In general all the studies had similar aims, but some had different approaches, and consequently slightly different results. In the study by Cucchiara et $\mathrm{al}^{27}$ omeprazole decreased clinical score by $83 \%$, improved histological and endoscopic degree of esophagitis by $75 \%$ and $82 \%$, 
Table I Clinical trials testing delayed-release omeprazole in children

\begin{tabular}{|c|c|c|c|c|c|c|c|c|}
\hline Author & Study design & $\begin{array}{l}\text { Trial data } \\
\text { (country, } \\
\text { center) }\end{array}$ & $\begin{array}{l}\text { No of } \\
\text { treated } \\
\text { children }\end{array}$ & Age & Formulation & Dosage & $\begin{array}{l}\text { Duration } \\
\text { of therapy }\end{array}$ & $\begin{array}{l}\text { Measured } \\
\text { parameters }\end{array}$ \\
\hline Cucchiara $^{27}$ & RCT & $\begin{array}{l}\text { Italy, } \\
\text { single-center }\end{array}$ & 12 & $6 \mathrm{mo}-13.4 \mathrm{y}$ & $\begin{array}{l}\text { capsule content } \\
\text { or capsule }\end{array}$ & $\begin{array}{l}40 \mathrm{mg} / \mathrm{l} .73 \\
\mathrm{~m}^{2} / \mathrm{die}\end{array}$ & $8 w k$ & $\begin{array}{l}\text { symptoms, } \\
\text { esophageal } \\
\text { and gastric pH } \\
\text { monitoring, } \\
\text { endoscopic and } \\
\text { histological degree } \\
\text { of esophagitis }\end{array}$ \\
\hline Moore $\mathrm{el}^{4}$ & $\begin{array}{l}\text { RCT, } \\
\text { double-blind, } \\
\text { placebo } \\
\text { controlled, } \\
\text { crossover }\end{array}$ & $\begin{array}{l}\text { Australia, } \\
\text { multi-center }\end{array}$ & 15 & $3-12 \mathrm{mo}$ & $\begin{array}{l}\text { microspheres in } \\
\text { apple juice }\end{array}$ & $\begin{array}{l}\text { 5-10 kg: } \\
10 \mathrm{mg} / \mathrm{die} ; \\
>10 \mathrm{~kg}: \\
10 \mathrm{mg} / \mathrm{bid}\end{array}$ & $2 w k$ & $\begin{array}{l}\text { symptoms, } \\
\text { esophageal } \mathrm{pH} \\
\text { monitoring }\end{array}$ \\
\hline Hassal $^{42}$ & CT, open-label & $\begin{array}{l}\text { Multinational, } \\
\text { multi-center }\end{array}$ & 57 & $1-16 y$ & $\begin{array}{l}\text { capsule or } \\
\text { granules in } \\
\text { weakly acid } \\
\text { vehicle for } \\
\text { children unable } \\
\text { to swallow intact } \\
\text { capsule }\end{array}$ & $\begin{array}{l}0.7-3.5 \mathrm{mg} / \\
\mathrm{kg} / \mathrm{die}\end{array}$ & $12 \mathrm{wk}$ & $\begin{array}{l}\text { symptoms, } \\
\text { endoscopic degree } \\
\text { of esophagitis }\end{array}$ \\
\hline Alliët ${ }^{18}$ & CT, open-label & $\begin{array}{l}\text { Belgium, } \\
\text { single-center }\end{array}$ & 12 & $2-3.8 \mathrm{mo}$ & $\begin{array}{l}\text { capsule content } \\
\text { in milk or water }\end{array}$ & $\begin{array}{l}0.5 \mathrm{mg} / \mathrm{kg} / \\
\mathrm{die}=20 \mathrm{mg} / \\
\mathrm{l} .73 \mathrm{~m}^{2} / \mathrm{die}\end{array}$ & 6 wk & $\begin{array}{l}\text { symptoms, gastric } \\
\mathrm{pH} \text { monitoring, } \\
\text { endoscopic and } \\
\text { histological degree } \\
\text { of esophagitis }\end{array}$ \\
\hline Bishop 17 & CT, open-label & $\begin{array}{l}\text { UK, } \\
\text { single-center }\end{array}$ & 10 & $1.25-20 \mathrm{mo}$ & $\begin{array}{l}\text { multiple unit } \\
\text { pellet system } \\
\text { dissolved in } \\
\text { alkaline vehicle }\end{array}$ & $\begin{array}{l}0.7-2.8 \mathrm{mg} / \\
\mathrm{kg} / \mathrm{die}\end{array}$ & $2 w k$ & $\begin{array}{l}\text { symptoms, } \\
\text { esophageal } \\
\text { and gastric pH } \\
\text { monitoring }\end{array}$ \\
\hline Cucchiara $^{43}$ & CT, open-label & $\begin{array}{l}\text { Italy, } \\
\text { single-center }\end{array}$ & 22 & $19 \mathrm{mo}-12 \mathrm{y}$ & $\begin{array}{l}\text { content of the } \\
\text { capsule in acid } \\
\text { vehicle as } \\
\text { grapefruit or } \\
\text { orange juice }\end{array}$ & $\begin{array}{l}\mathrm{I} \mathrm{mg} / \mathrm{kg} / \\
\mathrm{die}=40 \mathrm{mg} / \\
\mathrm{l} .73 \mathrm{~m}^{2} / \mathrm{die}\end{array}$ & $8 w k$ & $\begin{array}{l}\text { symptoms, } \\
\text { endoscopic degree } \\
\text { of esophagitis }\end{array}$ \\
\hline Kato 22 & CT, open-label & $\begin{array}{l}\text { Japan, } \\
\text { single-center }\end{array}$ & 5 & $3-18 y$ & $\begin{array}{l}\text { enteric coated } \\
\text { preparation }\end{array}$ & $\begin{array}{l}0.3-1.6 \mathrm{mg} / \\
\mathrm{kg} / \mathrm{die}\end{array}$ & $2-8 w k$ & $\begin{array}{l}\text { symptoms, gastric } \\
\mathrm{pH} \text { monitoring, } \\
\text { endoscopic degree } \\
\text { of esophagitis }\end{array}$ \\
\hline De Giacomo ${ }^{44}$ & CT, open-label & $\begin{array}{l}\text { Italy, } \\
\text { single-center }\end{array}$ & 10 & $2-9 y$ & capsule content & $\begin{array}{l}<30 \mathrm{~kg}: \\
20 \mathrm{mg} / \mathrm{die} ; \\
>30 \mathrm{~kg}: \\
40 \mathrm{mg} / \mathrm{bid}\end{array}$ & $12 \mathrm{wk}$ & $\begin{array}{l}\text { symptoms, } \\
\text { esophageal pH } \\
\text { monitoring, } \\
\text { endoscopic and } \\
\text { histological degree } \\
\text { of esophagitis }\end{array}$ \\
\hline Karjoo 45 & CT, open-label & $\begin{array}{l}\text { USA, } \\
\text { single-center }\end{array}$ & 38 & $6-18 y$ & capsule content & $20-60 \mathrm{mg} / \mathrm{die}$ & $8 w k$ & symptoms \\
\hline Gunasekaran 25 & CT, open-label & $\begin{array}{l}\text { Canada, } \\
\text { single-center }\end{array}$ & 15 & $0.8-17 y$ & $\begin{array}{l}\text { capsule or } \\
\text { granules in } \\
\text { weakly acid } \\
\text { vehicle for } \\
\text { children unable } \\
\text { to swallow intact } \\
\text { capsule }\end{array}$ & $\begin{array}{l}0.7-3.3 \mathrm{mg} / \\
\mathrm{kg} / \mathrm{die}= \\
10-60 \mathrm{mg} / \mathrm{die}\end{array}$ & $24 \mathrm{wk}$ & $\begin{array}{l}\text { symptoms, } \\
\text { esophageal pH } \\
\text { monitoring, } \\
\text { endoscopic degree } \\
\text { of esophagitis }\end{array}$ \\
\hline
\end{tabular}

(Continued) 
Table I (Continued)

\begin{tabular}{|c|c|c|c|c|c|c|c|c|}
\hline Author & Study design & $\begin{array}{l}\text { Trial data } \\
\text { (country, } \\
\text { center) }\end{array}$ & $\begin{array}{l}\text { No. of } \\
\text { treated } \\
\text { children }\end{array}$ & Age & Formulation & Dosage & $\begin{array}{l}\text { Duration } \\
\text { of therapy }\end{array}$ & $\begin{array}{l}\text { Measured } \\
\text { parameters }\end{array}$ \\
\hline Boccia $^{46}$ & $\begin{array}{l}\mathrm{CT}, \\
\text { open-label }\end{array}$ & $\begin{array}{l}\text { Italy, } \\
\text { single-center }\end{array}$ & 48 & $2.7-14.2$ y & $\begin{array}{l}\text { capsule or } \\
\text { granules in } \\
\text { weakly acid } \\
\text { vehicle for } \\
\text { children unable } \\
\text { to swallow } \\
\text { intact capsule }\end{array}$ & $1.4 \mathrm{mg} / \mathrm{kg} / \mathrm{die}$ & $12 \mathrm{wk}$ & $\begin{array}{l}\text { symptoms, } \\
\text { endoscopic } \\
\text { degree of } \\
\text { esophagitis }\end{array}$ \\
\hline Strauss ${ }^{26}$ & $\begin{array}{l}\text { CT, } \\
\text { open-label }\end{array}$ & $\begin{array}{l}\text { USA, } \\
\text { single-center }\end{array}$ & 18 & $2-17 y$ & capsule content & $\begin{array}{l}0.26-1.35 \mathrm{mg} / \\
\mathrm{kg} / \mathrm{die}\end{array}$ & 8-I2 wk & $\begin{array}{l}\text { symptoms, } \\
\text { endoscopic } \\
\text { and histo- } \\
\text { logical degree of } \\
\text { esophagitis }\end{array}$ \\
\hline
\end{tabular}

Abbreviations: CT, controlled trial; die, once daily; RCT, randomized controlled trial.

respectively, and reduced esophageal acid exposure by $61.9 \%$ and intra-gastric acidity by $29 \%$. Moore et $\mathrm{a}^{41}$ reported significant reduction in reflux index without a significant reduction in irritability, which was the only evaluated symptom. In the study by Hassal et $\mathrm{al}^{42}$ omeprazole healed endoscopic esophagitis in $95 \%$ of children and improved reflux symptoms in $91.5 \%$ even in the unhealed children. Alliet et a ${ }^{18}$ reported symptom improvement in $67 \%$, endoscopic healing in $100 \%$ and histological healing in $67 \%$ of children and a significant reduction of intra-gastric acidity. Bishop et a ${ }^{17}$ reported a significant improvement both in reflux index and intra-gastric acidity and a significant improvement in clinical score in children younger than 2 years. In another study Cucchiara et $\mathrm{a}^{43}$ reported symptom resolution or improvement in all patients and improvement in the endoscopic degree of esophagitis in $76 \%$ of cases. Kato et $\mathrm{al}^{22}$ reported symptom improvement in all children, endoscopic healing of esophagitis in $80 \%$ of children and significant reduction of intra-gastric acidity. De Giacomo et $\mathrm{a}^{44}$ showed endoscopic, but not histological, healing of esophagitis in $90 \%$ of treated children, symptoms improvement in $100 \%$ and a significant reduction in reflux index. Karjoo et $\mathrm{a}^{45}$ reported symptom improvement in $87 \%$ of treated children. Gunasekaran et $\mathrm{a}^{25}$ reported symptom resolution, esophageal acid exposure within normal range and endoscopic healing of esophagitis in $100 \%$ of children by 6 months of treatment. Boccia et a ${ }^{46}$ reported endoscopic healing of esophagitis in $96 \%$ of children and symptom resolution in $35 \%$. Strauss et $\mathrm{al}^{26}$ showed symptom resolution or improvement in $100 \%$, histological healing of esophagitis in $37.5 \%$ and endoscopic healing in $100 \%$ of children.
For the purpose of our analysis, the studies were divided in subgroups according to the outcome parameters measured. Table 2 shows esophageal and gastric $\mathrm{pH}-$ monitoring, Table 3 shows endoscopic and histological results, and Figure 1 shows percentage of asymptomatic children after treatment.

All studies evaluated symptom relief/resolution, even if the symptoms considered and the scores used to graduate their presence/intensity were not homogeneous. GERD symptom improvement or disappearance were reported as percentage of asymptomatic children in 10 studies s $^{18,22,25-27,42-46}$ and showed symptomatic response in 189 out of 235 treated children $(80.4 \%)$ but rate of symptom relief widely varied ranging from $35 \%$ to $100 \%$ (Figure 1). In 2 studies $^{17,41}$ the clinical score only was reported, and was significantly decreased in 1 study. ${ }^{17}$

Five studies ${ }^{17,25,27,41,44}$ evaluated reduction of esophageal reflux index, 4 studies ${ }^{17,18,22,27}$ measured reduction of intragastric acidity ( 2 of them monitored both the esophageal and the gastric $\mathrm{pH}$ ). Out of these 5 studies analyzing the esophageal 24-hour $\mathrm{pH}$ profile, 4 were comparable since they reported homogeneous data, ie, the median percentage of time of esophageal $\mathrm{pH}<4$ (reflux index) before and after omeprazole treatment. In all studies reflux index was significantly decreased and was always within normal limits (ie, $<7 \%$ ) ranging from $1 \%$ to $5.4 \%$. Out of the 4 studies measuring reduction of intra-gastric acidity, 3 were comparable since they homogeneously reported the median percentage of time of gastric $\mathrm{pH}<4$ both before and after treatment. Percentage of time of gastric $\mathrm{pH}<4$ significantly decreased from $20 \%$ to $69 \%$. 
Table 2 Studies evaluating esophageal and/or gastric $\mathrm{pH}$-monitoring

\begin{tabular}{|c|c|c|c|}
\hline Author & $\begin{array}{l}\text { No of treated } \\
\text { children }\end{array}$ & $\begin{array}{l}\text { Esophageal pH-monitoring } \\
\% \text { of time of esophageal pH }<4\end{array}$ & $\begin{array}{l}\text { Gastric } \mathrm{pH}-\text {-monitoring \% of time } \\
\text { of gastric } \mathrm{pH}<4\end{array}$ \\
\hline Cucchiara $^{27}$ & 12 & $\begin{array}{l}\text { before treatment } 9 \text { after treatment } \\
\text { 3.1 } \Delta-5.9\end{array}$ & $\begin{array}{l}\text { before treatment } 90.3 \text { after treatment } \\
60.3 \Delta-30\end{array}$ \\
\hline Moore ${ }^{41}$ & 15 & $\begin{array}{l}\text { before treatment } 9.9 \text { after } \\
\text { treatment I } \Delta-8.9\end{array}$ & \\
\hline Alliët ${ }^{18}$ & 12 & & $\begin{array}{l}\text { before treatment } 90.3 \text { after treatment } \\
21.3 \Delta-69\end{array}$ \\
\hline Bishop ${ }^{17}$ & 10 & $\begin{array}{l}\text { before treatment } 18.5 \text { after } \\
\text { treatment } 1.6 \Delta-16.9\end{array}$ & $\begin{array}{l}\text { before treatment } 71.9 \text { after treatment } \\
\text { 13.2 } \Delta-58.7\end{array}$ \\
\hline Kato $^{22}$ & 5 & & after treatment 72.2 \\
\hline De Giacomo ${ }^{44}$ & 10 & $\begin{array}{l}\text { before treatment } 17 \text { after treatment } \\
5.4 \Delta-11.6\end{array}$ & \\
\hline Gunasekaran 25 & 15 & $\begin{array}{l}\text { before treatment range II-88 after } \\
\text { treatment } \leq 6\end{array}$ & \\
\hline
\end{tabular}

Nine studies evaluated the rate of healing of esophagitis in term of endoscopic healing ${ }^{18,22,25-27,42-44,46}$ and in 4 of them histological healing was also evaluated. ${ }^{18,26,27,44}$ For the purpose of our analysis, we considered as endoscopically healed a macroscopically normal esophageal mucosa, corresponding to grades 0 and 1 of Hetzel and Dent scale. ${ }^{47}$ According to this criterion, patients presenting a grade 1 esophagitis at baseline were excluded from the calculation for the healing rate. The majority of children where endoscopic healing was reported were treated for 12 weeks or longer and healing tended to be better than in children treated for 8 weeks or less $(P=0.053)$. Histological healing was defined according to different criteria, so results were non comparable and we analyzed only the percentage of children reported as histologically healed. Overall the histological healing rate was significantly lower than the endoscopic healing in these 4 studies ( $49 \%$ vs $91 \%, P=0.0001$ ).

\section{Discussion}

In this review evidences about the efficacy of omeprazole treatment for esophagitis in children have been systematically reviewed. Efficacy has been evaluated in terms of symptom relief, normalization or improvement of gastric and/or esophageal acidity, and endoscopic and/or histological healing of esophagitis.

In 10 of 12 studies omeprazole was very effective in improving or resolving GERD symptoms, both when evaluated as a percentage of asymptomatic children or as a decreased symptom score. However, in 2 studies efficacy on symptoms was lower, particularly on irritability. Moore et $\mathrm{al}^{41}$ reported that omeprazole did not significantly reduce irritability score in infants. However, irritability being evaluated by subjective methods, such as a diary of crying and fussing time and a visual analogue score of parental impression of its intensity was the only symptom evaluated. And when efficacy on reducing esophageal $\mathrm{pH}$ was assessed even in these infants a significant reduction in reflux index was seen. Similarly Boccia et $\mathrm{al}^{46}$ reported a low symptom resolution rate of $35 \%$. However, analyzing each reported symptom even in this study irritability was the only non-improving one, whereas frequency of other symptoms like vomiting,

Table 3 Studies evaluating rates of endoscopic and/or histological healing of esophagitis

\begin{tabular}{llll}
\hline Author & Duration of therapy & Endoscopic healing & Histological healing \\
\hline Cucchiara $^{27}$ & $8 \mathrm{wk}$ & $9 / 11(82 \%)$ & $9 / 12(75 \%)$ \\
Hassa $^{42}$ & $12 \mathrm{wk}$ & $54 / 57(95 \%)$ & $8 / 12(67 \%)$ \\
Alliët $^{18}$ & $6 \mathrm{wk}$ & $12 / 12(100 \%)$ & \\
Cucchiara $^{43}$ & $8 \mathrm{wk}$ & $13 / 17(76 \%)$ & \\
Kato $^{22}$ & $2-8 \mathrm{wk}$ & $4 / 5(80 \%)$ & $0 / 10$ \\
De Giacomo $^{44}$ & $12 \mathrm{wk}$ & $9 / 10(90 \%)$ & \\
Gunasekaran $^{25}$ & $24 \mathrm{wk}$ & $6 / 6(100 \%)$ & \\
Boccia $^{46}$ & $12 \mathrm{wk}$ & $46 / 48(96 \%)$ & \\
Strauss $^{26}$ & $8-12 \mathrm{wk}$ & $1 / 1(100 \%)$ & $6 / 14(43 \%)$ \\
\hline
\end{tabular}

Notes: In 115 of 121 children treated for 12 weeks or longer endoscopic healing rate was $95 \%$ ( $95 \%$ Cl $89-98)$. In 38 of 45 children treated for 8 weeks or shorter endoscopic healing rate was $84 \%(95 \% \mathrm{Cl} 7 \mathrm{I}-93)$. 


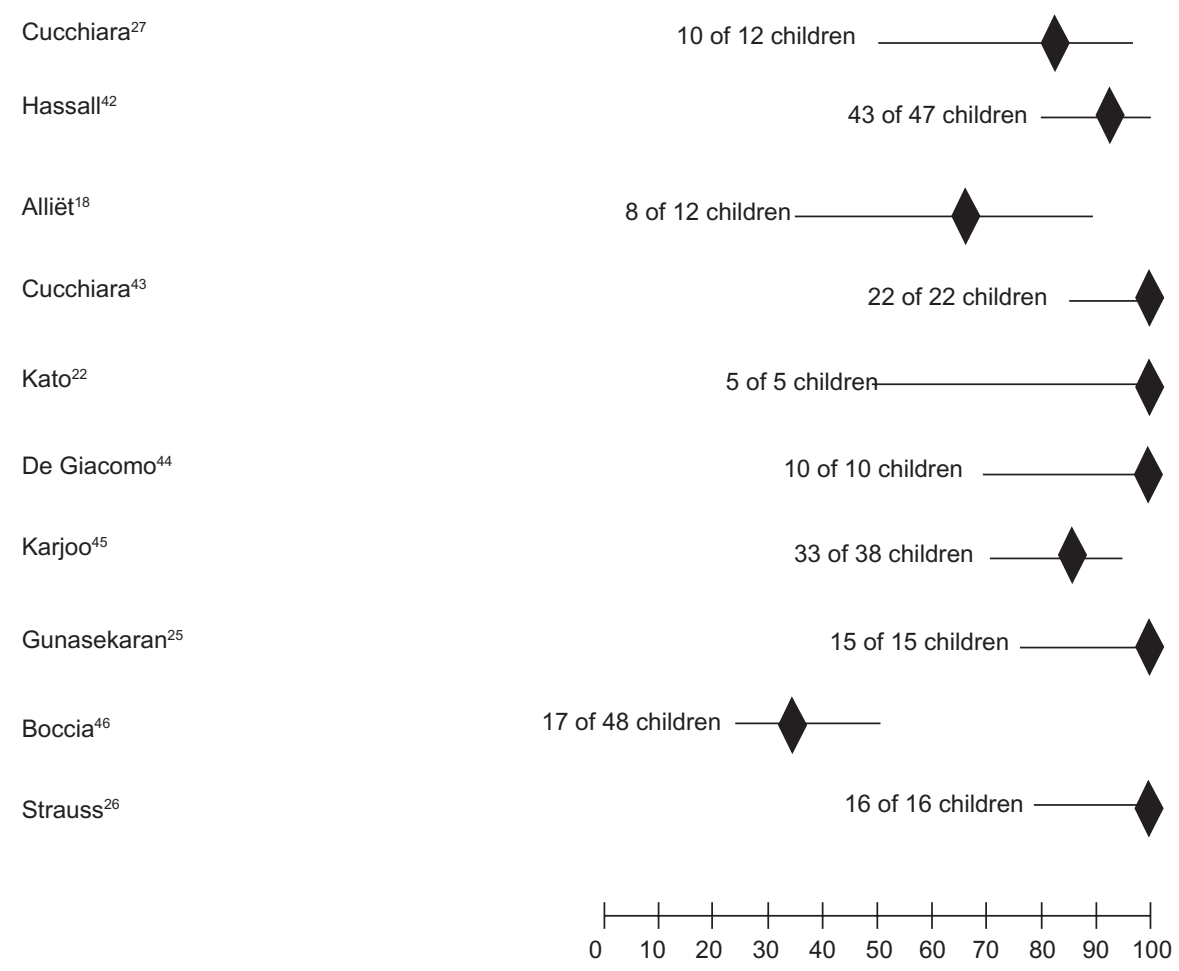

Figure I Symptom resolution rates in the 10 studies reporting percentage of asymptomatic children after treatment.

heartburn, epigastric pain, and dysphagia significantly decreased. Therefore, the failure of omeprazole in treating irritability, despite effective acid suppression and significant efficacy on other symptom improvement, may be explained by the hypothesis that some infants/children could be irritable because of non-acid reflux or irritability could be a selflimiting condition tending to improve only over time.

The efficacy of omeprazole in suppressing acid output has been demonstrated by esophageal ${ }^{17,25,27,41,44}$ and/or gastric $^{17,18,22,27} \mathrm{pH}$ monitoring or both. ${ }^{17,27}$ In particular, all the studies analyzing esophageal $\mathrm{pH}$-monitoring showed an effective acid suppression by omeprazole, reducing the percentage of time of esophageal $\mathrm{pH}<4$ to less than $6 \%$, a reflux index $>7 \%$ being considered abnormal according to recent guidelines of North American and European Society for Pediatric Gastroenterology. ${ }^{48}$

Omeprazole resulted to be very effective in healing esophagitis in children. Although data are analyzed in different way from studies performed in adults, and so results are not completely comparable, efficacy in children seems to be better than in adults. Indeed, a recent systematic review ${ }^{49}$ reported the overall endoscopic healing for omeprazole in adults of $73.8 \%$ (95\% CI 71-76) and in our children treated for 8 weeks or less was similar $(84 \%, 95 \%$ CI $71-93)$ but in those treated for 12 weeks or longer healing rate was significantly higher $(95 \%, 95 \%$ CI $89-98)$. The possible better efficacy of omeprazole in children might be due to the higher dosage used in children, in whom doses of omeprazole are given on a per kilogram basis; or, alternatively, to a lesser severity of the inflammatory changes due to a shorter duration of the reflux disease in the younger population. However, when analyzed, the histological healing even in children was significantly lower, and in 2 studies $^{26,44}$ histological parameters did not correlate with endoscopic healing or symptomatic relief.

Comparing omeprazole with other most common drugs or surgical approaches used for GERD and esophagitis treatment in children, omeprazole seem to be more effective. Most of the children successfully treated with omeprazole included in this review were unresponsive to previous medical treatments with anti-acids, H2-receptor blockers, pro-kinetic agents or surgery. However, when looking more carefully at the data presented the higher efficacy of omeprazole compared to ranitidine is not proven. Karjoo et $\mathrm{al}^{45}$ initially treated children with $8 \mathrm{mg} / \mathrm{kg}$ once daily ranitidine, increasing to $12 \mathrm{mg} / \mathrm{kg}$ once daily if no symptomatic improvement was observed after 2 weeks, but this apparent failure of ranitidine could be due to a too short period of observation or, more probably, to a too low dosage of ranitidine. Indeed, when Cucchiara et $\mathrm{al}^{27}$ directly compared omeprazole $1 \mathrm{mg} / \mathrm{kg}$ once daily to ranitidine at the dose of $20 \mathrm{mg} / \mathrm{kg}$ once daily efficacy was similar in symptom relief, endoscopic and 
histological healing, and in reducing esophageal and gastric acidity, whereas the same children previously treated with ranitidine at the dosage of $8 \mathrm{mg} / \mathrm{kg}$ once daily had not responded. Dosage of ranitidine is known to correlate with the esophageal reflux index and a dose lower than $10 \mathrm{mg} / \mathrm{kg}$ dail is indeed ineffective to heal esophagitis. ${ }^{50}$ However, data on the similarity of ranitidine and omeprazole efficacy in the treatment of childhood esophagitis are insufficient and other head-to-head studies are necessary, particularly because in adults omeprazole was reported to have a superior efficacy to H2-receptor blockers in treating esophagitis. ${ }^{51}$

Similarly, data on usefulness of maintenance therapy or in-demand therapy for prevention of recurrence in children are insufficient. Only in 1 study ${ }^{46}$ were children followed after healing and maintenance therapy for longer enough to assess prevalence of relapse and found symptoms recurrence only in $6.8 \%$ of children even after maintenance discontinuation, unsupporting the necessity of maintenance therapy.

\section{Conclusion}

In conclusion, delayed-release oral suspension of omeprazole given at a median dosage of $1 \mathrm{mg} / \mathrm{kg}$ once daily for a median duration of 12 weeks showed high efficacy in treating GERD and esophagitis in children. Moreover, thanks to its safety and tolerability omeprazole use in childhood can be extended to clinical settings. The need for a long-term maintenance therapy, however, is still to be assessed in the pediatric population.

\section{Disclosures}

The authors report no conflicts of interest in this work.

\section{References}

1. Sherman PM, Hassall E, Fagundes-Neto U, et al. A global, evidencebased consensus on the definition of gastroesophageal reflux disease in the pediatric population. Am J Gastroenterol. 2009;104:1278-1295.

2. Nelson SP, Chen EH, Syniar GM, Christoffel KK. Prevalence of symptoms of gastroesophageal reflux during childhood: a pediatric practice-based survey. Pediatric Practice Research Group. Arch Pediatr Adolesc Med. 2000;154:150-154.

3. Vandenplas Y, Hauser B. Gastro-oesophageal reflux, sleep pattern, apparent life threatening event and sudden infant death. The point of view of a gastro-enterologist. Eur J Pediatr. 2000;159:726-729.

4. Ghaem M, Armstrong KL, Trocki O, Cleghorn GJ, Patrick MK, Shepherd RW. The sleep patterns of infants and young children with gastro-oesophageal reflux. J Paediatr Child Health. 1998;34:160-163.

5. Cerimagic D, Ivkic G, Bilic E. Neuroanatomical basis of Sandifer's syndrome: a new vagal reflex? Med Hypotheses. 2008;70:957-961.

6. Dahshan A, Patel H, Delaney J, Wuerth A, Thomas R, Tolia V. Gastroesophageal reflux disease and dental erosion in children. J Pediatr. 2002; 140:474-478.

7. Debley JS, Carter ER, Redding GJ. Prevalence and impact of gastroesophageal reflux in adolescents with asthma: a population-based study. Pediatr Pulmonol. 2006;41:475-481.
8. Størdal K, Johannesdottir GB, Bentsen BS, Carlsen KC, Sandvik L. Asthma and overweight are associated with symptoms of gastro-oesophageal reflux. Acta Paediatr. 2006;95:1197-1201.

9. Block BB, Brodsky L. Hoarseness in children: the role of laryngopharyngeal reflux. Int J Pediatr Otorhinolaryngol. 2007;71:1361-1369.

10. El-Serag HB, Bailey NR, Gilger M, Rabenek L. Endoscopic manifestations of gastroesophageal reflux disease in patients between 18 months and 25 years without neurological deficits. Am J Gastroenterol. 2002;97:1635-1639.

11. Hassall E. Endoscopy in children with GERD: "the way we were" and the way we should be. Am J Gastroenterol. 2002;97:1583-1586.

12. Sharma P, McQuaid K, Dent J, et al. A critical review of the diagnosis and management of Barrett's esophagus: the AGA Chicago Workshop. Gastroenterology. 2004;127:310-330.

13. Tighe MP, Afzal NA, Bevan A, Beattie RM. Current pharmacological management of gastro-esophageal reflux in children: an evidence-based systematic review. Paediatr Drugs. 2009;11:185-202.

14. Israel DM, Hassall E. Omeprazole and other proton pump inhibitors: pharmacology, efficacy, and safety, with special reference to use in children. J Pediatr Gastroenterol Nutr. 1998;27:568-579.

15. Andersson T, Hassall E, Lundborg P, et al. Pharmacokinetics of orally administered omeprazole in children. International Pediatric Omeprazole Pharmacokinetic Group. Am J Gastroenterol. 2000;95:3101-3106.

16. Zimmermann AE, Walters JK, Katona BG, Souney PE, Levine D. A review of omeprazole use in the treatment of acid-related disorders in children. Clin Ther. 2001;23:660-679.

17. Bishop J, Furman M, Thomson M. Omeprazole for gastroesophageal reflux disease in the first 2 years of life: a dose-finding study with dual-channel pH monitoring. J Pediatr Gastroenterol Nutr. 2007;45: $50-55$.

18. Alliët P, Raes M, Bruneel E, Gillis P. Omeprazole in infants with cimetidine-resistant peptic esophagitis. J Pediatr. 1998;132:352-354.

19. Zimmermann AE, Walters JK, Katona B, Souney P. Alternative methods of proton pump inhibitor administration. Consult Pharm. 1997; 12:990-998.

20. Hassall E, Kerr W, El-Serag HB. Characteristics of children receiving proton pump inhibitors continuously for up to 11 years duration. J Pediatr. 2007;150:262-267.

21. Tolia V, Boyer K. Long-term proton pump inhibitor use in children: a retrospective review of safety. Dig Dis Sci. 2008;53:385-393.

22. Kato S, Ebina K, Fujii K, Chiba H, Nakagawa H. Effect of omeprazole in the treatment of refractory acid-related diseases in childhood: endoscopic healing and twenty-four-hour intragastric acidity. J Pediatr. 1996;128:415-421.

23. Tayman C, Mete E, Catal F, Tonbul A. Hypersensitivity reaction to omeprazole in a child. J Investig Allergol Clin Immunol. 2009;19(1):76-77.

24. Canani RB, Cirillo P, Roggero P, et al. Working Group on Intestinal Infections of the Italian Society of Pediatric Gastroenterology, Hepatology and Nutrition (SIGENP). Therapy with gastric acidity inhibitors increases the risk of acute gastroenteritis and community-acquired pneumonia in children. Pediatrics. 2006;117:e817-e820.

25. Gunasekaran TS, Hassall EG. Efficacy and safety of omeprazole for severe gastroesophageal reflux in children. J Pediatr. 1993;123: $148-154$.

26. Strauss RS, Calenda KA, Dayal Y, Mobassaleh M. Histological esophagitis: clinical and histological response to omeprazole in children. Dig Dis Sci. 1999;44:134-139.

27. Cucchiara S, Minella R, Iervolino C, et al. Omeprazole and high dose ranitidine in the treatment of refractory reflux oesophagitis. Arch Dis Child. 1993;69:655-659.

28. Hassall E, Dimmick JE, Israel DM. Parietal cell hyperplasia in children receiving omeprazole (abstract). Gastroenterology. 1995;108:A121.

29. Israel DM, Dimmick JE, Hassall E. Gastric polyps in children on omeprazole (abstract). Gastroenterology. 1995;108:A110.

30. Pashankar DS, Israel DM. Gastric polyps and nodules in children receiving long-term omeprazole therapy. J Pediatr Gastroenterol Nutr. 2002;35:658-662. 
31. Oosterhuis B, Jonkman JHG. Omeprazole: Pharmacology, pharmacokinetics and interactions. Digestion. 1989;44(Suppl 1):9-17.

32. Andersson T, Andren K, Cederberg C, Edvardsson G, Heggelund A, Lundborg P. Effect of omeprazole and cimetidine on plasma diazepam levels. Eur J Clin Pharmacol. 1990;39:51-54.

33. Gugler R, Jensen JC. Omeprazole inhibits oxidative drug metabolism. Studies with diazepam and phenytoin in vivo and 7-ethoxycoumarin in vitro. Gastroenterology. 1985;89:1235-1241.

34. Sutfin T, Balmer K, Gaström H, Eriksson S, Höglund P, Paulsen O. Stereoselective interaction of omeprazole with warfarin in healthy men. Ther Drug Monit. 1989;11:176-184.

35. Cohen AF, Kroon R, Schoemaker HX, Hoogkamer H, van Vliet A. Influence of gastric acidity on the bioavailability of digoxin. Ann Intern Med. 1991;115:540-555.

36. Red T, Yem A, Cadillac M, Carlson RW. Impact of omeprazole on the plasma clearance of methotrexate. Cancer Chem Pharmacol. 1993;33:82-84.

37. Gugler R, Jensen JC. Drugs other than H2-receptor antagonists as clinically important inhibitors of drug metabolism in vivo. Pharmacol Ther. 1987;33:133-137.

38. Taburet AM, Geneve J, Bocquentin M, Simoneau G, Caulin C, Singlas E. Theophylline steady state pharmacokinetics is not altered by omeprazole. Eur J Clin Pharm. 1992;42:343-345.

39. Henry D, Brent P, Whyte I, Mihaly G, Devenish-Meares S. Propranolol steady-state pharmacokinetics are unaltered by omeprazole. Eur J Clin Pharmacol. 1987;33:369-373.

40. Blohme I, Andersson T, Idström JP. No interaction between omeprazole and cyclosporine. Br J Clin Pharmacol. 1993;35:155-160.

41. Moore DJ, Tao BS, Lines DR, Hirte C, Heddle ML, Davidson GP. Double-blind placebo-controlled trial of omeprazole in irritable infants with gastroesophageal reflux. J Pediatr. 2003;143:219-223.

42. Hassall E, Israel D, Shepherd R, et al. Omeprazole for treatment of chronic erosive esophagitis in children: a multicenter study of efficacy, safety, tolerability and dose requirements. International Pediatric Omeprazole Study Group. J Pediatr. 2000;137:800-807.
43. Cucchiara S, Minella R, Campanozzi A, et al. Effects of omeprazole on mechanisms of gastroesophageal reflux in childhood. Dig Dis Sci. 1997:42:293-299.

44. De Giacomo C, Bawa P, Franceschi M, Luinetti O, Fiocca R. Omeprazole for severe reflux esophagitis in children. J Pediatr Gastroenterol Nutr. 1997;24:528-532.

45. Karjoo M, Kane R. Omeprazole treatment of children with peptic esophagitis refractory to ranitidine therapy. Arch Pediatr Adolesc Med. 1995;149:267-271.

46. Boccia G, Manguso F, Miele E, Buonavolontà R, Staiano A. Maintenance therapy for erosive esophagitis in children after healing by omeprazole: is it advisable? Am J Gastroenterol. 2007;102: 1291-1297.

47. Hetzel DJ, Dent J, Reed WD, et al. Healing and relapse of severe peptic esophagitis after treatment with omeprazole. Gastroenterology. 1988;95:903-912.

48. Vandenplas Y, Rudolph CD, Di Lorenzo C, et al. Pediatric Gastroesophageal Reflux Clinical Practice Guidelines: Joint Recommendations of the North American Society of Pediatric Gastroenterology, Hepatology, and Nutrition and the European Society of Pediatric Gastroenterology, Hepatology, and Nutrition. J Pediatr Gastroenterol Nutr. 2009;49:498-547.

49. Edwards SJ, Lind T, Lundell L, DAS R. Systematic review: standardand double-dose proton pump inhibitors for the healing of severe erosive oesophagitis - a mixed treatment comparison of randomized controlled trials. Aliment Pharmacol Ther. 2009;30:547-556.

50. Salvatore S, Hauser B, Salvatoni A, Vandenplas Y. Oral ranitidine and duration of gastric $\mathrm{pH}>4.0$ in infants with persisting reflux symptoms. Acta Paediatr. 2006;95:176-181.

51. Khan M, Santana J, Donnellan C, Preston C, Moayyedi P. Medical treatments in the short term management of reflux oesophagitis. Cochrane Database Syst Rev. 2007 Apr 18;(2):CD003244.
Clinical and Experimental Gastroenterology

\section{Publish your work in this journal}

Clinical and Experimental Gastroenterology is an international, peerreviewed, open access journal, publishing all aspects of gastroenterology in the clinic and laboratory, including: Pathology, pathophysiology of gastrointestinal disease; Investigation and treatment of gastointestinal disease; Pharmacology of drugs used in the alimentary tract;

\section{Dovepress}

Immunology/genetics/genomics related to gastrointestinal disease. This journal is indexed on CAS. The manuscript management system is completely online and includes a very quick and fair peer-review system. Visit http://www.dovepress.com/testimonials.php to read real quotes from published authors. 